\title{
Geoclemys hamiltonii (Gray 1830) - Spotted Pond Turtle, Black Pond Turtle
}

\author{
INDRANEIL DAS ${ }^{1}$ AND S. BHUPATHY ${ }^{2}$ \\ ${ }^{1}$ Institute of Biodiversity and Environmental Conservation, \\ Universiti Malaysia Sarawak, 94300 Kota Samarahan, Sarawak, Malaysia [idas@ibec.unimas.my]; \\ ${ }^{2}$ Sálim Ali Centre for Ornithology and Natural History, \\ Anaikatty(PO), Coimbatore 641 108, Tamil Nadu, India [bhupathy.s@gmail.com]
}

\begin{abstract}
Summary. - The spotted pond turtle, Geoclemys hamiltonii (Family Geoemydidae), is a mediumsized (straight carapace length to $40.5 \mathrm{~cm}$ ) freshwater turtle from lentic waterbodies of the northern and northeastern Indian subcontinent. The species is primarily carnivorous, feeding on snails and insect larvae, but vegetative material has been found in some digestive tracts. Two clutches of 18-30 eggs are produced annually, eggs measuring ca. 51 x $21 \mathrm{~mm}$. Drainage of standing water bodies for agriculture and urbanization and capture for food are factors suspected to threaten wild populations. The species has been reported to be rapidly declining in Bangladesh, but populations in a few protected areas in India are apparently relatively abundant.

Distribution. - Pakistan, India, Nepal, Bangladesh. Distributed from eastern Pakistan, through the Ganga basin of northern India, to Bangladesh and northeastern India.

Synonymy.-Emys hamiltonii Gray 1830, Clemmys (Clemmys) hamiltonii, Geoclemys hamiltonii, Damonia hamiltonii, Emys guttata Gray 1831, Emys picquotii Lesson 1831, Melanochelys pictus Murray 1884, Clemmys palaeindica Lydekker 1885, Geoclemys sivalensis Tewari and Badam 1969.

SubSPECIES. - None recognized.

STATUS.-IUCN 2010 Red List: Vulnerable (A1d+2d) (assessed 2000); CITES: Appendix I; Indian Wildlife (Protection) Act: Schedule I; Bangladesh Wildlife (Preservation) Act: Schedule III.
\end{abstract}

Taxonomy. - Emys hamiltonii Gray 1830 was described from an unspecified locality in India. Synonyms include Emys guttata Gray 1831, Emys picquotii Lesson 1831, Melanochelys pictus Murray 1884, and the PlioPleistocene turtles, Clemmys palaeindica Lydekker 1885 and Geoclemys sivalensis Tewari and Badam 1969. No subspecies have been described and geographic variation, if any, is unknown. The species is the genotype for the monotypic genus Geoclemys Gray 1856.

Description. - The shell is convex, strongly arched with sloping sides and three prominent, interrupted keels on the carapace. The plastron is narrow and deeply notched posteriorly. The head is extremely large, short-snouted, and the skin at the back of the forehead is divided into shields.

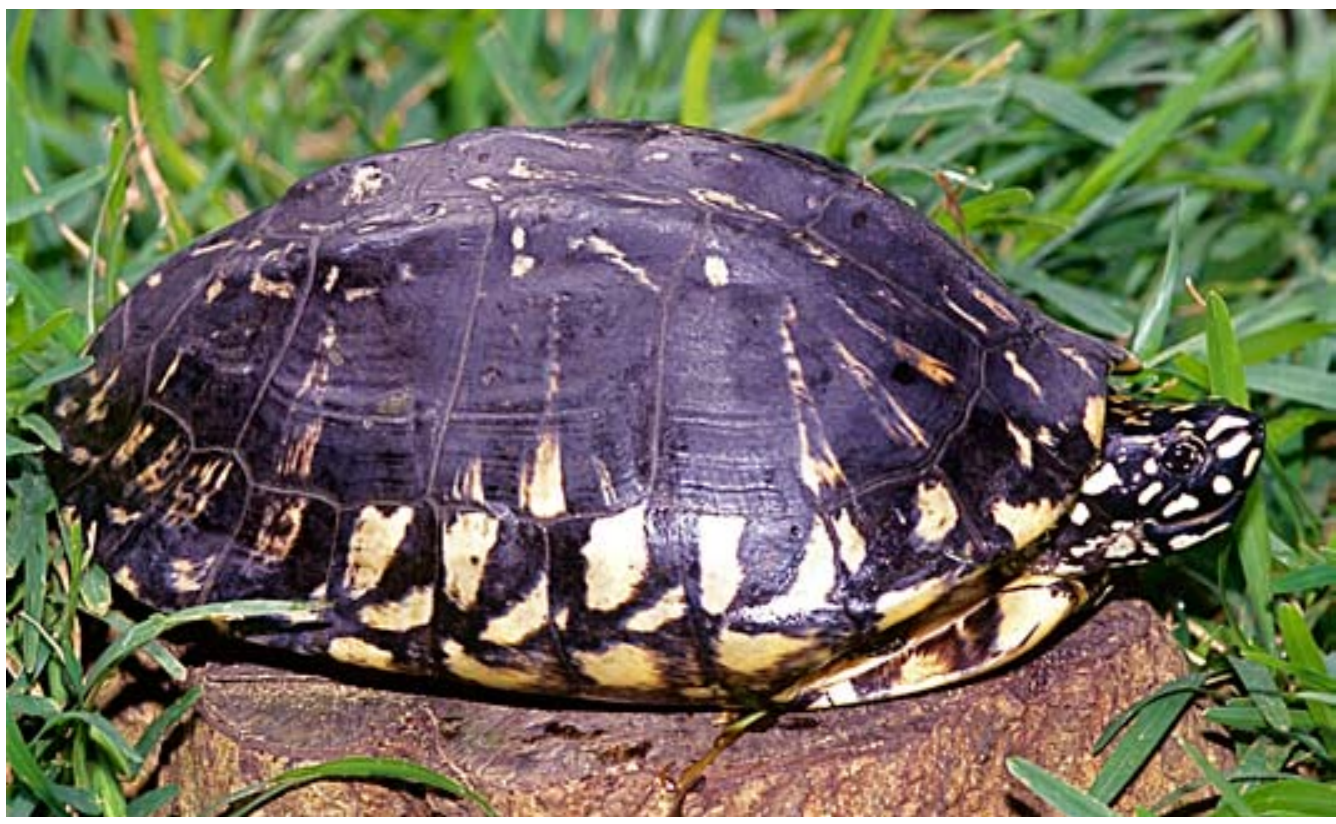

Figure 1. Geoclemys hamiltonii, adult female from Kaziranga National Park, Assam, India. Photo by Indraneil Das. 


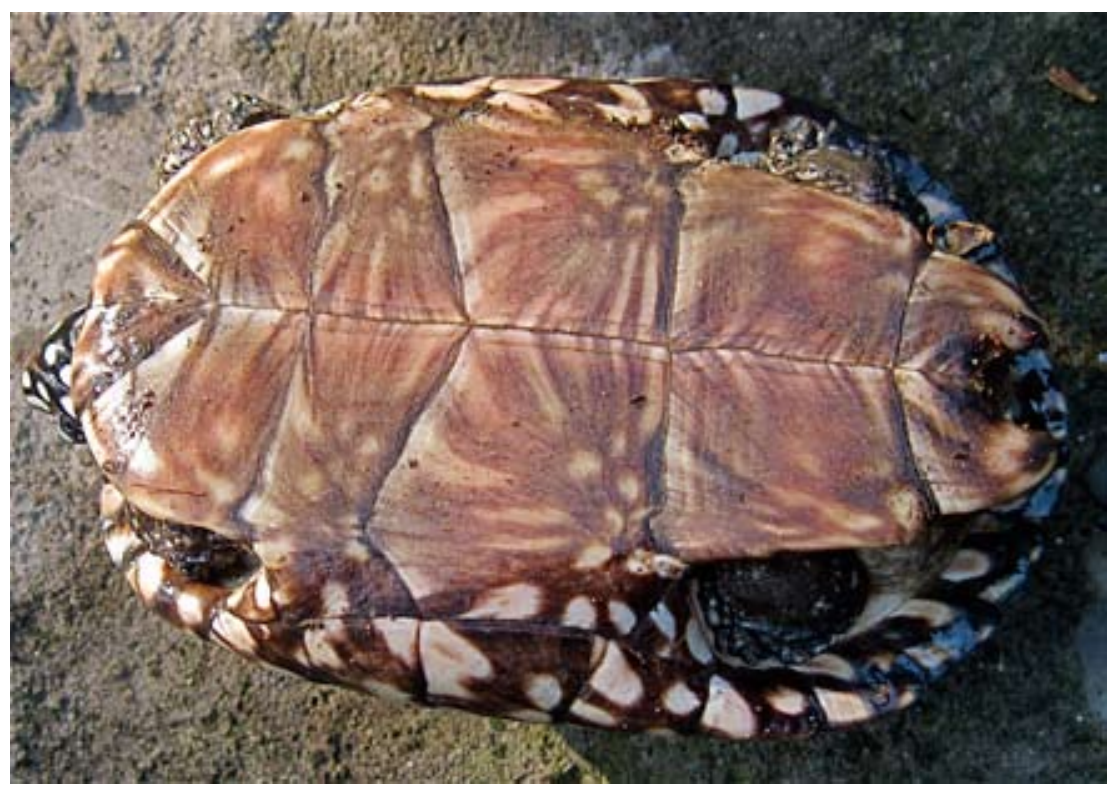

Figure 2. Geoclemys hamiltonii, plastron of subadult from Assam, northeast India. Photo by Chittaranjan Baruah.

Digits are completely webbed. The shell is black with yellow streaks and wedge-shaped marks. The head is black with yellow spots, whereas the neck is gray with white spots. The eyes are also black and the iris has yellow spots.

The sexes differ little in size, but females may be slightly larger, and attain a carapace length (CL) of $405 \mathrm{~mm}$. Rashid and Swingland (1997) found that 14 live females from Bangladesh averaged $301.4 \mathrm{~mm}$ in CL (range 207-405), and 13 males averaged $292.2 \mathrm{~mm}$ (range 211-392). The largest male weighed $5.2 \mathrm{~kg}$ and the largest female $6 \mathrm{~kg}$. Males possess thicker tails and concave plastra. Ewert (1979) noted that hatchlings had a CL of $37.2 \mathrm{~mm}$. Fossil specimens from the Plio-Pleistocene, otherwise similar to the extant form, attained a larger size than is known today (Das 1991a).

The karyotype is $2 \mathrm{n}=52$ (Rohilla et al.2006). Geoclemys hamiltonii is phylogenetically distinctive; weak molecular support has been shown for a relationship to Orlitia, Malayemys, and the Batagur-Pangshura-Hardella-Morenia group (Spinks et al.2004). Rohilla and Tiwari (2008) presented data from cyt-b and $16 \mathrm{~S}$ rDNA segments from the mitochondrial genome, for use in forensic identification. No phylogeographic studies of the species have been undertaken.

Distribution. - The spotted pond turtle ranges across the northern part of the Indian subcontinent, its distribution extending from eastern Pakistan, through the Ganga basin of northern India and Bangladesh, to northeastern India (Smith 1931; Vijaya 1983). Bhadauria et al. (1995) reported the species from the Gomti and Girwa rivers in Uttar Pradesh, in northern India, and Gaur (2009) from the Aravalli foothills. In Bangladesh, it may now be confined primarily to the southeast and south, specifically the districts of Faridpur, Barisal, Patuakhali, Bakerhat, and Noakhali (Rashid and Swingland 1997). Moll and Vijaya's (1986) record of the species from the vicinity of Gandak Dam in India's Bihar State suggests that it may also be found in neighboring Nepal, and subsequently,
Shrestha (1996a) reported it to be a "common resident" of that country, although it was considered rare in the Karnali River system (Shrestha 1996b). Schleich and Kästle (2002) knew of no Nepalese records for the species.
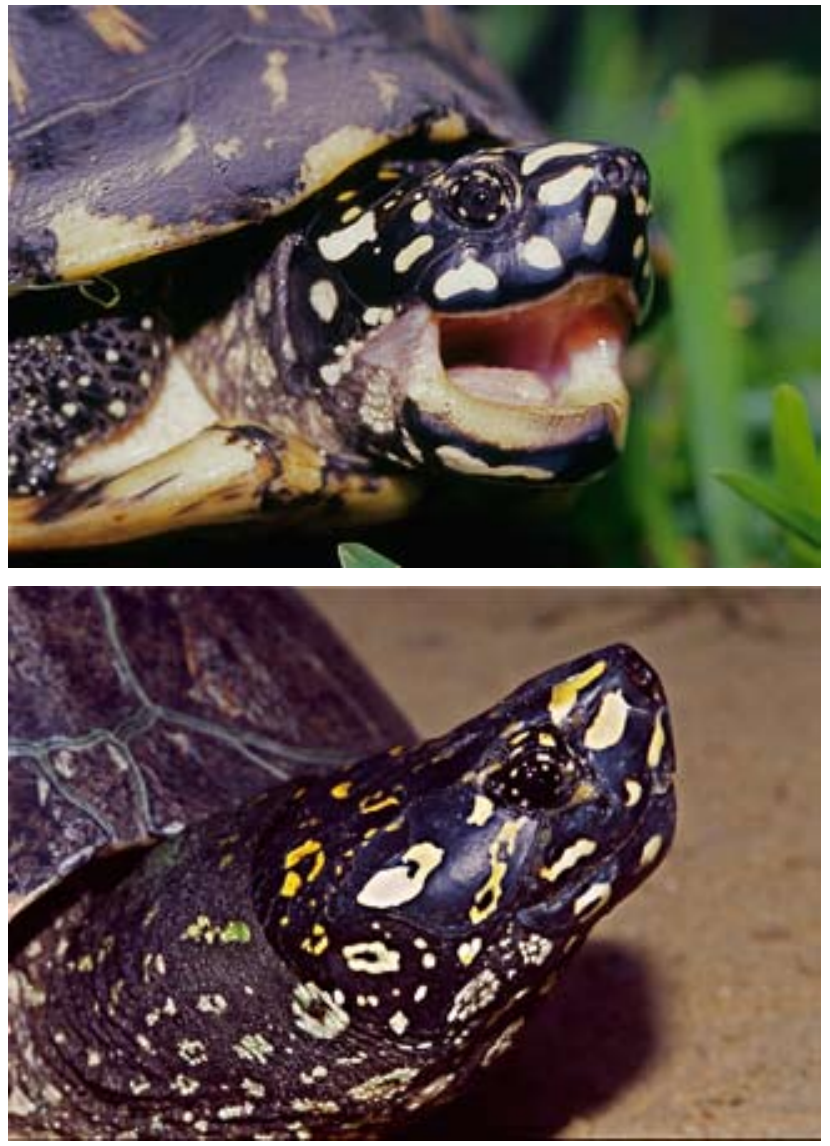

Figure 3. Geoclemys hamiltonii, adults from Kaziranga National Park, on the River Brahmaputra,India (top, photo by Indraneil Das), and Kukrail Gharial Centre, on the River Ganga, India (bottom, photo by Peter Paul van Dijk). 


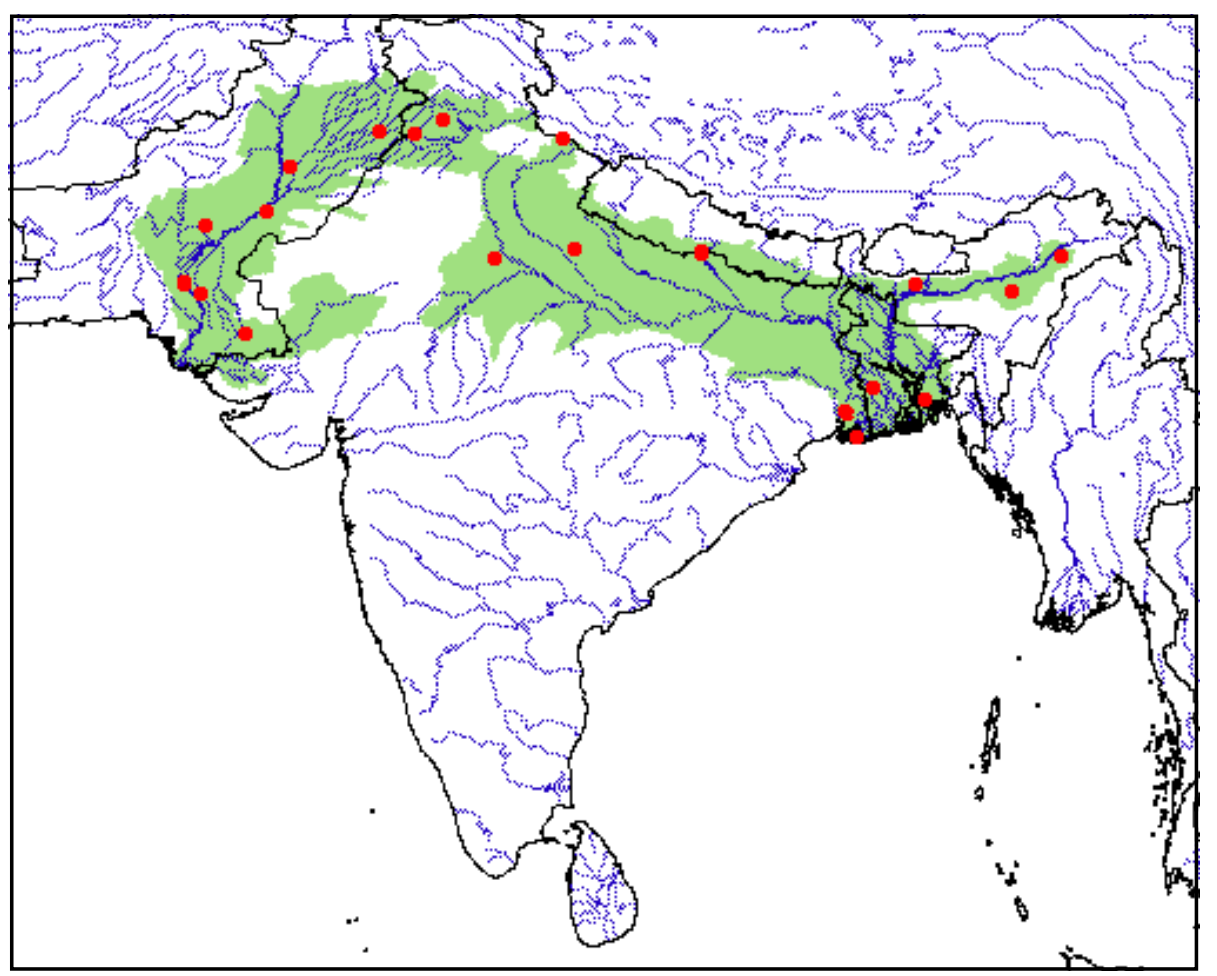

Figure 4. Distribution of Geoclemys hamiltonii in the northern Indian subcontinent. Red points = museum and literature occurrence records based on Iverson (1992) plus more recent and authors' data; green shading = projected distribution based on GIS-defined hydrologic unit compartments (HUCs) constructed around verified localities and then adding HUCs that connect known point localities in the same watershed or physiographic region, and similar habitats and elevations as verified HUCs (Buhlmann et al. 2009), and adjusted based on authors' data.
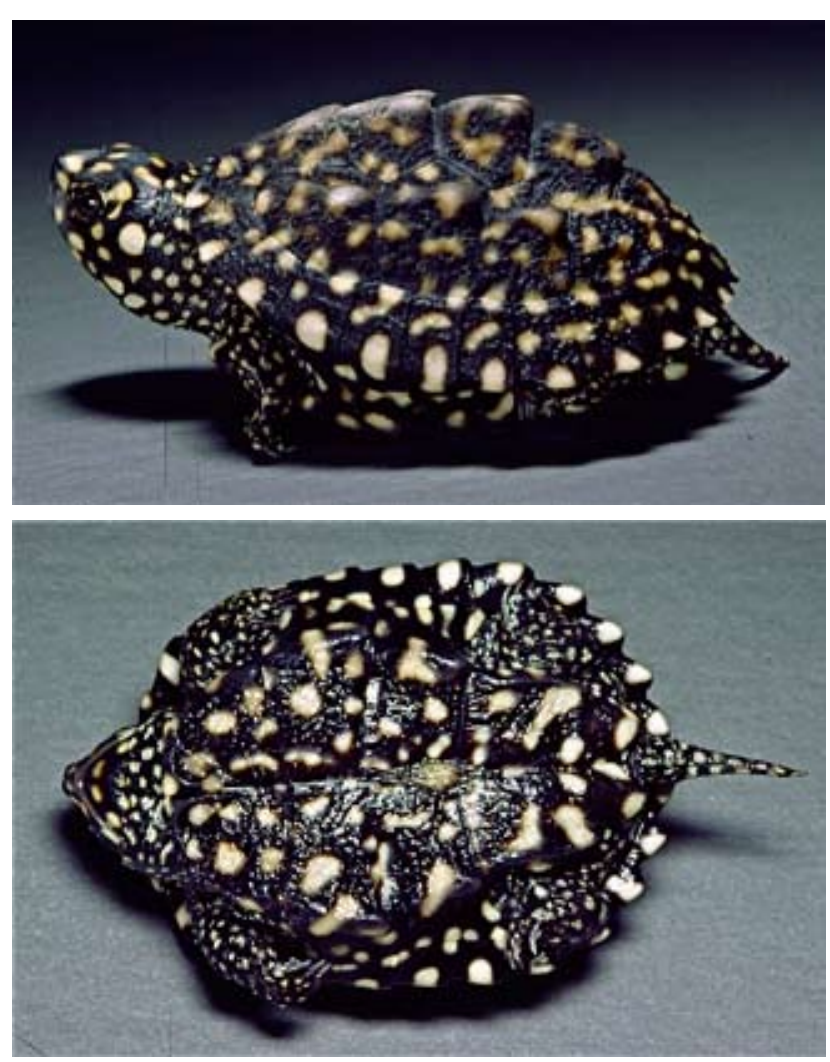

Figure 5. Geoclemys hamiltonii, hatchling born in captivity of parents of unknown provenance. Photos by Peter Paul van Dijk.

Habitat and Ecology. - This species is, in most places, almost entirely restricted to shallow standing waters, especially oxbow lakes. Prakash (1982) noted that in the Thar Desert of Rajasthan, western India, it is also found in rivers, in addition to ponds that dry up in summer. During this period, the spotted pond turtle migrates to wells dug up in the river bed, and can dig down deep in such sites. In Kaziranga National Park,Assam, in northeast India, the turtle uses macrophyte-filled oxbow lakes, with basking taking place on the reed-dominated banks (Das 1991b). Also in this protected area, during March, several individuals have been sighted resting on mounds of thick vegetation cover, surrounded by water. In Bangladesh, Rashid and Swingland (1997) reported that this species is found on land as well as in water. During the winter, it remains under bushes, dry vegetation, water hyacinths, water weeds, and dry leaves. In summer, it typically resides in water and may bask on the banks or on floating objects, or it may float for extended periods with its head breaking the surface. Primarily crepuscular in habit, it emits a low croak while retracting its neck, and rarely bites (Khan 2006).

The relatively large head of the species may be used for molluscivory. Minton (1966) collected turtles from Pakistan that voided snail opercula, in addition to algae, which were considered to have been swallowed incidentally. At Bharatpur, Rajasthan, India, it feeds on snails (Lemnaea spp. and Gyrulus spp.) and odonate larvae (Das 1995). The rhamphotheca and bony surfaces of the jaws show traces of a cusp-and-ridge pattern, described by McDowell (1964), 
which may be for crushing snail shells. The stomachs of Bangladesh specimens contained grasses, cereals, plant fiber, shells, legs of crabs, prawns, and other crustaceans, fish bones, and undigested muscle tissue; water skater, waterbug, freshwater snails, prawns, and freshwater mussels were also identified (Rashid and Swingland 1997). The white scavenger vulture (Neophron percnopterus) is a predator of this turtle in the marshes of Bharatpur during the summer months (Bhupathy, unpubl. data). A nematode, Falcaustra bengalensis, has been recorded from this species by Manna and Mahapatra (1989).

In captivity, sexual maturity is attained in 6-8 yrs (Gurley 2003). Rashid and Swingland (1977) reported that, in Bangladesh, the first clutch is laid between mid-December and mid-January, and a second between late February and early March. Nests are dug in bushy areas in loamy soil, and the nest is bowl-shaped and 6-10 cm in depth. The first clutch generally numbers 20-30 eggs and the second slightly fewer (18-28). The oval, white eggs average 51.3 $\mathrm{mm}$ in length, $21.1 \mathrm{~mm}$ in width, and $11.5 \mathrm{~g}$ in mass. The eggs hatch at the beginning of the rainy season (May-June). In Uttar Pradesh, northern India, eggs are laid in April and May, clutch size there was 13-24 eggs (Basu and Singh 1998), although the known maximum clutch size for the species may be as high as 36 , and eggs measure ca. $45 \times 25$ $\mathrm{mm}$ (Das 2001). A specimen with 26 well developed eggs was observed in Kaziranga at the end of March (Bhupathy and Choudhury 1993). In captivity, Artner (2006) reported clutch sizes in the range of 12-25, incubation periods of 50-60 days at $27-30^{\circ} \mathrm{C}$, and hatchling CL of 35.5-38.4 $\mathrm{mm}$.

Population Status. - As with most freshwater turtles in the region, no specific estimates of population size have been attempted, and no records of former abundance are available. In India, the species may be locally common at a few sites, such as Kaziranga National Park in Assam, eastern India, where Bhupathy and Choudhury (1994) reported 18 specimens during two days of field work.

In Bangladesh, Rashid and Swingland (1997) and Rashid and Khan (2000) reported that the species is rare and rapidly declining, due to commercial exploitation for meat, and to some extent from habitat loss. Formerly distributed throughout the country, it was then confined primarily to the south-central and southern regions. It is widely distributed from the Haor Basin to eastern Mymensingh and Sylhet, but numbers are low and appear to be declining. Although previously known from the wetlands of Khulna District, heavy exploitation in the recent past has caused local extirpation.

In the five major rivers of Pakistan's Punjab Province, the species has been reported as being "frequent" relative to other sympatric freshwater turtles (Akbar et al. 2006).

Threats to Survival. - Conversion of the lentic water habitat of the spotted pond turtle into rice fields and other agricultural lands, land filling for human settlements, and aquatic pollution are factors suspected to have impacted the species. Significant numbers are caught for the consumption trade, with consumer centers in eastern India, especially the Howrah market, near Kolkata, up to the late 1980s (Das 1991b). Choudhury and Bhupathy (1993) found no turtles in the aforementioned market in 1993. According to Khan (1987), the Hindus in Bangladesh catch the turtle with hooks or by probing in the mud during the low water months of the winter. In recent years, quite large numbers of $G$. hamiltonii have appeared in urban markets in China. Most probably these turtles originated in Bangladesh, where Rashid and Swingland (1997) reported that the species is easily captured by collectors who use nets, fences, and sometimes spears, or by hand. In Punjab Province, Pakistan, the species is considered a predator of fish, and is killed when found in nets or via angling by fishermen (Akbar et al. 2006).

In Nepal, Shrestha (1996a) reported that an extract of the carapace and plastron of $G$. hamiltonii is offered to children showing subnormal or stunted growth. The Kanjar tribe in the Rajghat and Bhartinagar area of Uttar Pradesh, northern India, hunt the turtle for food as well as for making combs, which is a small-scale industry (Hanfee 1995).

This attractive species is sometimes observed in the pet markets locally (Datta 1998), as well as those in the US and Western Europe (see Ceballos and Fitzgerald 2004), and has been seen in southeast Asian pet shops in recent years: Shepherd and Nijman (2008) reported observing six individuals at the Chatuchak Market, Bangkok, Thailand, between the years 2006-07. In Kuching, East Malaysia, hatchlings retail for around Ringgit Malaysian 800 (equivalent to US\$ 250) each (Das, pers. obs., May 2010).

Conservation Measures Taken. - The species is covered under Schedule I of the Indian Wildlife (Protection) Act of 1972 and Schedule III of the Bangladesh Wildlife (Preservation) Act of 1974. It is also listed on Appendix I of CITES. The current IUCN Red List designation is Vulnerable, as assessed in 2000.

The establishment of sanctuaries along the GangaBrahmaputra river systems appears to have benefited the species, the largest known population probably being in Kaziranga National Park, Assam State, India. Other significant populations exist in Orang Wildlife Sanctuary and Dibru Saikhowa National Park (Assam State), Keoladeo National Park (Rajasthan State), and Harike Wildlife Sanctuary (Punjab State), all in India.

Conservation Measures Proposed. - An active education program for people living in areas where it is consumed is warranted. Captive breeding for release in areas where populations have been depleted through overharvesting may be a suitable conservation strategy for this species, but only if guarantees can be obtained that will protect the released animals. International trade to Chinese consumption markets needs to be curtailed.

Captive Husbandry. - Schmidt (1964) maintained a pair in shallow water (twice shell depth), at temperatures between $22-25^{\circ} \mathrm{C}$, and noted that these turtles were not good swimmers. Chopped fish and beef were accepted, but hardly any vegetables. The male was aggressive to the female, as well as other turtles, both on land and in water. A pair 
maintained at the Madras Crocodile Bank Trust in a shallow artificial cement pool accepted fish but refused plant matter. This species has been kept and bred in Europe (see Rotmans and Rotmans-Zwaal 1994; Reams 1997; Artner 2006) and in Florida where Wayne Hill of Winter Haven maintains a captive colony of these turtles that reproduce successfully every year. They have also been captive-bred by Anthony Wisniewski of Baltimore, Maryland.

Current Research. - No information available.Astudy of the status and biology of this species is long overdue.

Acknowledgments. - Supported by the Centre for Herpetology, Madras Crocodile Bank Trust, Universiti Malaysia Sarawak, Bombay Natural History Society, and Sálim Ali Centre for Ornithology and Natural History. We thank John Iverson for comments on the manuscript, and Chittaranjan Baruah and Peter Paul van Dijk for images.

\section{LITERATURE CITED}

Akbar, M.,MushtaQ-Ul-Hassan, M., andZaib-u-Nisa. 2006.Distribution of freshwater turtles in Punjab, Pakistan. Caspian Journal of Environmental Sciences 4:142-146.

Artner, H. 2006. Geoclemys hamiltonii (Gray, 1831), the spotted pond turtle: first F2-breeding in captivity. In: Artner, H., Farkas, B., and Loehr, V. (Eds.). Turtles. Proceedings: International Turtle \& Tortoise Symposium, Vienna 2002.Edition Chimaira,Frankfurt am Main. pp. 111-125.

BASU,D. AND SINGH, S.P. 1998. Reproduction in Geoclemys hamiltonii (Testudines: Bataguridae). Hamadryad 23:157-161.

Bhadauria, R.S., Singh, A.N., AND Mishra, S.B. 1995. Morphometrics and taxonomy of spotted black terrapin Geoclemys hamiltonii (Gray, 1831). Tigerpaper 22(3):27-30.

Bhupathy, S. AND ChOUdHURY, B.C. 1994. A note on the reproductive biology of the spotted pond turtle. Journal of the Bombay Natural History Society 91:146-147.

Buhlmann, K.A., Akre, T.S.B., Iverson, J.B., Karapatakis, D., MitTERMEIER, R.A., Georges, A., Rhodin, A.G.J., van DiJK, P.P., AND GibBons, J.W. 2009. A global analysis of tortoise and freshwater turtle distributions with identification of priority conservation areas. Chelonian Conservation and Biology 8(2):116-149.

Ceballos, C.P. and Fitzgerald, L.A. 2004. The trade in native and exotic turtles in Texas. Wildlife Society Bulletin 32:881-891.

Choudhury, B.C. And Bhupathy, S. 1993.Turtle Trade in India. World Wide Fund for Nature - India, New Delhi. 50 pp.

DAS, I. 1991a. The taxonomic status of the Pleistocene turtle Geoclemys sivalensis. Journal of Herpetology 25:104-107.

DAS, I. 1991b. Colour Guide to the Turtles and Tortoises of the Indian Subcontinent. R \& A Publishing Limited, Portishead. 133 pp.

DAS, I. 1995. Turtles and Tortoises of India. Oxford University Press, Bombay. 174 pp.

DAS,I. 2001.Die Schildkröten des Indischen Subkontinents.Edition Chimaira, Frankfurt am Main. 160 pp.

DatTA, A. 1998. Records of turtles from Pakhui Wildlife Sanctuary, Arunachal Pradesh, northeast India. Journal of the Bombay Natural History Society 95:121-123.

EwERT,M.A. 1979. The embryoand the egg: development and natural history.In:Harless,M. andMorlock,H.(Eds.).Turtles: Perspectives and Research. Wiley Interscience, New York. pp. 333-416.

GAUR, S. 2009. Species richness and dominance of reptiles in the Aravalli foothills of Rajasthan. In: Sivaperuman, C., Baqri, Q.H.,
Ramaswamy, G., and Naseema, M. (Eds.). Faunal Ecology and Conservation of the Great Indian Desert. Springer-Verlag, Berlin and Heidelberg, pp. 53-64.

Gray, J.E. 1830. A Synopsis of the Species of the Class Reptilia. In: Griffith E. and Pidgeon, E. The Class Reptilia arranged by the Baron Cuvier, with specific descriptions. In: Griffith,E.(Ed.).The Animal KingdomArranged in Conformity with its Organization, by the Baron Cuvier, with Additional Descriptions of all the Species Hitherto Named, and of many not before Noticed. Vol.9. Reptilia. Supplement. London: Whittaker, Treacher, and Co., 110 pp.

GRAY,J.E. 1831. Illustrations of IndianZoology, chiefly selected from the collection of Major-General Hardwicke. Vol. I, Part 6, pl. 76. London: Treuttel, Wurtz, Treuttel, Jun. and Richter.

Gray, J.E. 1856 [“1855”]. Catalogue of Shield Reptiles in the Collection of the British Museum. Part I. Testudinata (Tortoises). London: British Museum, 79 pp.

Gurley, R. 2003. Keeping and Breeding Freshwater Turtles. Living Art Publishing, Ada, Oklahoma, 297 pp.

HANFEE, F. 1995. Notes on freshwater turtle exploitation, Uttar Pradesh, India. TRAFFIC Bulletin 15(3):120-121.

Iverson, J.B. 1992. A Revised Checklist with Distribution Maps of the Turtles of the World. Privately published, Richmond, IN, 363 pp.

KHAN, M.A.R. 1987. Bangladesher Bonnyoprani. Vol. I. Urochor o Shorishrip. Bangla Academy, Dhaka, 169 pp.

Khan, M.S. 2006. Amphibians and Reptiles of Pakistan. Krieger Publishing Company, Malabar, Florida, 311 pp.

Lesson, R.-P. 1831. Catalogue des reptiles, qui font partie d'une collection zoologique recueillie dans l'Inde continentale ou en Afrique, et apportée en France par M. Lamare-Piquot. Catalogue dressé (Juillet 1830). Bulletin des Sciences Naturelles et de Géologie 25(4):119-123.

LyDEKKER, R. 1885. Indian Tertiary and Post-Tertiary Vertebrata. Siwalik and Narmada Chelonia. Memoirs of the Geological Survey of India Palaeontologica Indica, Series 10, 3:155-208.

Manna, B. AND Mahapatra, M.S. 1989. Falcaustra bengalensis sp. nov.(Kathlaniidae: Nematoda) from a turtle Geoclemys hamiltoni (Gray, 1831). Indian Journal of Animal Health 28:133-138.

MCDowell, S.B. 1964. Partition of the genus Clemmys and related problems in the taxonomy of the aquatic Testudinidae. Proceedings of the Zoological Society of London 1964:239-279.

Minton, S.A. 1966. A contribution to the herpetology of West Pakistan. Bulletin of the American Museum of Natural History 134:27-184.

Moll, E.O. AND ViJaYA, J. 1986. Distributional records for some Indian turtles. Journal of the Bombay Natural History Society 83:57-62.

MurRay, J.A. 1884. Additions to the reptilian fauna of Sind. Annals and Magazine of Natural History, Series 5, 14:106-111.

Prakash, I. 1982. The Thar: a desert alive. Sanctuary Asia 2(2):130-137.

Rashid, S.M.A. AND KHAN, S.M.H. 2000. Overview of turtle trade in Bangladesh. In: van Dijk, P.P., Stuart, B.L., and Rhodin, A.G.J. (Eds.). Asian Turtle Trade: Proceedings of a Workshop on Conservation and Trade in Freshwater Turtles and Tortoises in Asia. Chelonian Conservation Monographs 2:77-85.

RASHID, S.M.A. AND Swingland, I.R. 1997. On the ecology of some freshwater turtles in Bangladesh. In: Van Abbema, J. (Ed.). Proceedings: Conservation, Restoration, and Management of Tortoises and Turtles- An International Conference.New York Turtle and Tortoise Society, New York. pp. 225-242.

REAms, R. 1997. Notes on the natural history and husbandry of Hamilton's pond turtle (Geoclemys hamiltonii) at Lowry Park 
Zoo. The Vivarium 8(4):6-7.

RoHILLA, M.S. AND TIWARI, P.K. 2008. Restriction fragment length polymorphism of mitochondrial DNA and phylogenetic relationships among five species of Indian freshwater turtles. Journal of Applied Genetics 49(2):167-182.

RoHILLA, M.S., RAO, R.J., AND TiWARI, P.K. 2006. Use of peripheral blood lymphocyte culture in the karyological analysis of Indian freshwater turtles, Lissemys punctata and Geoclemys hamiltoni. Current Science 90:1130-1134.

Rotmans, H.J. and Rotmans-Zwaal, A.C. 1994. Een geslaagde kweek van de driekiel-straalschildpad (Geoclemys hamiltonii). Lacerta 53:11-17.

SChleich, H.H. AND Kästle, W. 2002. Order Chelonia/Testudines (turtles: terrapins \& tortoises). In: Schleich, H.-H. and Kästle, W. (Eds). Amphibians and Reptiles of Nepal. Biology, Systematics, Field Guide. Koeltz Scientific Books, Königstein. pp. 501-573.

Schмid, A. 1964. Die Strahlen-dreikielschildkröte, Geoclemys hamiltonii (Gray). Die Aquarien- und Terrarien-Zeitschrift 17:243-244.

SHEPHERD, C.R. AND NiJMAn, V. 2008. Pet Freshwater Turtle and Tortoise Trade in Chatuchak Market, Bangkok, Thailand. TRAFFIC Southeast Asia, Kuala Lumpur, 16 pp.

SHRESTHA, T.K. 1996a. New survival of rare chelonians in the altered habitats of Himalayan rivers of Nepal. In: Devaux, B. (Ed.). Proceedings of the International Congress of Chelonian Conservation. SOPTOM, Gonfaron, pp. 52-56.

SHRESTHA, T.K. 1996b. Wetland use, habitat fragmentation and their impacts on turtles in Nepal. In: Devaux, B. (Ed.). Proceedings of the International Congress of Chelonian Conservation.SOPTOM, Gonfaron. pp. 57-61.

Sмiтн, M.A. 1931. The Fauna of British India, including Ceylon and Burma. Vol. I. Loricata, Testudines. Taylor and Francis, London, $185 \mathrm{pp}$.

SpinKs, P.Q., Shaffer, H.B., Iverson, J.B., AND McCord, W.P. 2004. Phylogenetic hypothesis for the turtle family Geoemydidae. Molecular Phylogenetics and Evolution 32:164-182.

Tewari, B.S. and BadAM, G.L. 1969. A new species of fossil turtle from the Upper Siwalks of Pinjore, India. Paleontologica 12:555-558.

VIJAYA,J. 1983.Range extension for the spotted pond turtle Geoclemys hamiltoni. Hamadryad 8(2):20.

\section{Citation Format for this Account:}

DAs, I. AND Bhupathy, S. 2010. Geoclemys hamiltonii (Gray 1830) - spotted pond turtle, black pond turtle. In: Rhodin, A.G.J., Pritchard, P.C.H., van Dijk, P.P., Saumure, R.A., Buhlmann, K.A., Iverson, J.B., and Mittermeier, R.A. (Eds.). Conservation Biology of Freshwater Turtles and Tortoises: A Compilation Project of the IUCN/SSC Tortoise and Freshwater Turtle Specialist Group. Chelonian Research Monographs No. 5, pp. 043.1-043.6, doi:10.3854/crm.5.043 hamiltonii.v1.2010, http:// www.iucn-tftsg.org/cbftt/. 